\title{
Primary adenoid cystic carcinoma in the peripheral lung: a cytological, histopathological and immunohistochemical report of two cases
}

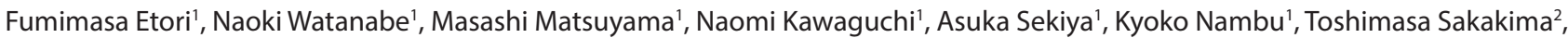
Toshiyuki Sawa ${ }^{3}$, Tsutomu Marui ${ }^{4}$, Takafumi Naiki ${ }^{2}$ and Takuji Tanaka ${ }^{1 *}$

*Correspondence: takutt@gmhosp.gifu.gifu.jp

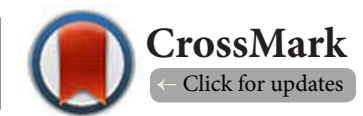

'Department of Diagnostic Pathology (DDP) \& Research Center of Diagnostic Pathology (RC-DiP), Gifu Municipal Hospital, 7-1 Kashima-cho, Gifu City, Gifu 500-8513, Japan.

${ }^{2}$ Department of Central Laboratory, Gifu Municipal Hospital, 7-1 Kashima-cho, Gifu City, Gifu 500-8513, Japan.

${ }^{3}$ Oncology Center, Gifu Municipal Hospital, 7-1 Kashima-cho, Gifu City, Gifu 500-8513, Japan.

${ }^{4}$ Department of Respiratory Surgery, Gifu Municipal Hospital, 7-1 Kashima-cho, Gifu City, Gifu 500-8513, Japan.

\begin{abstract}
Primary adenoid cystic carcinoma (ACC) of the peripheral lung is a rare entity. Here we report two cases of primary ACC. Case 1 is an 84-year-old male with a past-medical history of cecal cancer presented with a 10 mm left upper lung nodule. Case 2 is a 40-year-old female who presented with $30 \mathrm{~mm}$ right upper lobe. Intraoperative (Case 1) and pre-operative (Case 2) histopathologic and cytologic diagnoses were consistent with a primary peripheral lung ACC. An upper lobectomy \pm mediastinal lymph node dissection was performed and immunohistochemical staining with thyroid transcription factor (TTF)-1, c-KIT and MYB on the excision specimen confirmed our diagnosis.
\end{abstract}

Keywords: Adenoid cystic carcinoma, lung, cytology, immunohistochemistry, case reports

\section{Introduction}

Adenoid cystic carcinoma (ACC) is a biphasic tumor consisting of epithelial and myoepithelial cells. ACC is a rare, slow-growing low-grade malignancy which usually arises within salivary glands and tends to demonstrate local recurrence and frequent distant metastasis.

ACC also develops in several sites other than the salivary gland. Primary lung ACC is extremely rare and accounts for approximately $0.04 \%-0.2 \%$ of all lung cancers $[1,2]$. Primary lung ACC is categorized as a salivary-type lung cancer which mostly occurs in the trachea, carina, or in a main stem bronchus (70.7\%) [3]. An even rarer event is primary ACC in the peripheral lung within the parenchyma [4]. Only a few reports have so far described the cytologic findings of peripheral lung ACC $[4,5]$.

We recently diagnosed two cases of this rare malignancy via intra-operative frozen section and touch imprint in Case 1 and pre-operatively via biopsy and brush cytology (Case 2). Our diagnosis was confirmed by immunohistochemical steins.

\section{Case presentation}

\section{Case 1}

An 84-year-old Japanese male patient was admitted to our hospital for evaluation of an incidental left upper nodule. The patient had undergone surgery for cecal adenocarcinoma 33 month prior to this admission and the nodule was discovered on a post-operative chest computerized tomography (CT) examination (Figure 1). Although there were no abnormal positron emission tomography (PET) findings, the nodule size had increased over the past 3 years from $4 \mathrm{~mm}$ to $10 \mathrm{~mm}$. Clinically, a metastasis from his colon was suspected and therefore, surgical treatment was offered.

Past medical history was significant for a 1300 smoking index. The patient was otherwise asymptomatic on admission and had no co-existing diseases. His vital signs, physical examination, and laboratory findings, including serum tumor markers [CEA, $1.9 \mathrm{ng} / \mathrm{ml}$ ( $<5 \mathrm{ng} / \mathrm{ml}$ in normal); and ProGRP, $69.8 \mathrm{pg} /$ $\mathrm{ml}(\leq 80 \mathrm{pg} / \mathrm{ml}$ in normal)] were all within normal limits. The 
Etori et al. Pathology Discovery 2015,

patient underwent video-assisted thoracoscopic surgery to perform a partial resection of the left lung (Figure 2). There were no regional or mediastinal lymph node enlargements to suggest metastasis. Intraoperative frozen section (Figure 3a) and cytologic examination (Figure 4a) with touch imprint smears was performed and the diagnosis of peripheral lung ACC was made. A complete upper lobectomy was performed.

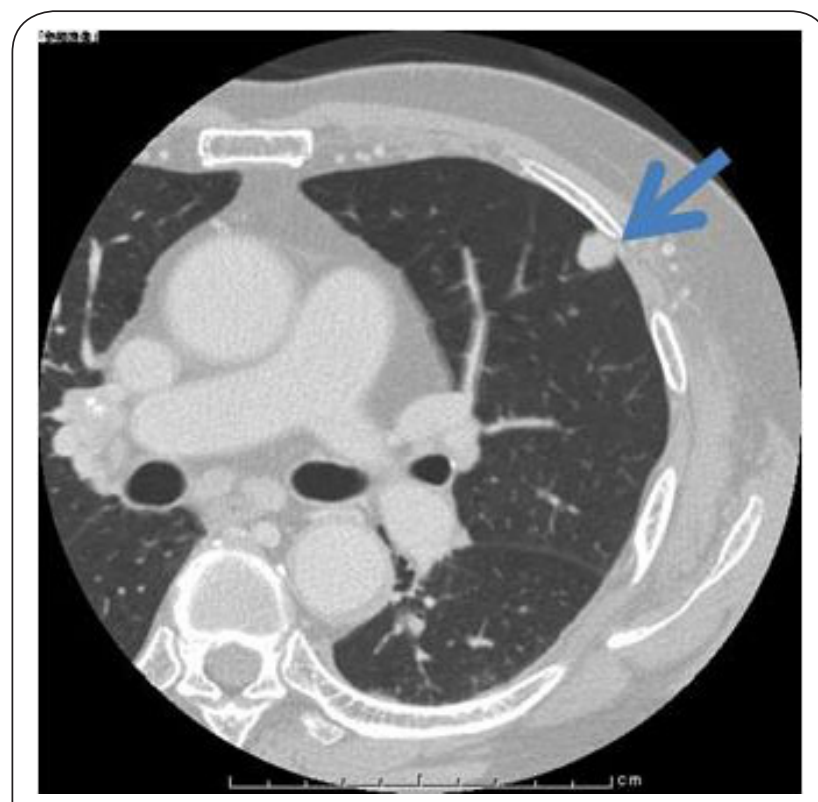

Figure 1. CT examination of Case 1 shows a round shape and a well circumscribed mass (arrow) in the left upper lobe without any lymph node swelling.

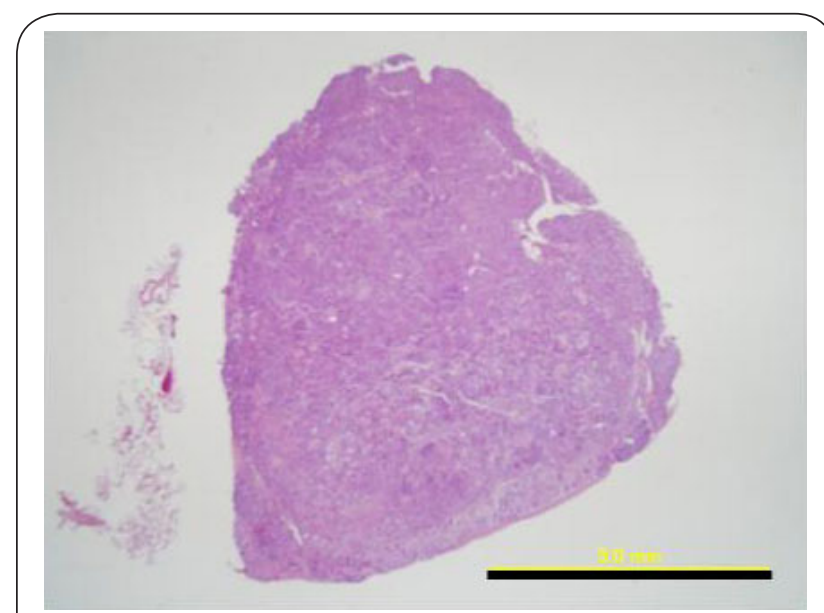

Figure 2. A close-up photo of the whole mount section that contains a resected tumor $(11 \times 10 \times 10 \mathrm{~mm})$ stained with $H \& E$ in the left upper lobe (Case 1). Note: a tumor is present beneath the pleura. A whole mount section shows a cellular and solid tumor with well-defined demarcation. It is adjacent to the visceral pleura devoid of any bronchial transition. H\&E stain, whole mount section, scale bar, $5 \mathrm{~mm}$.
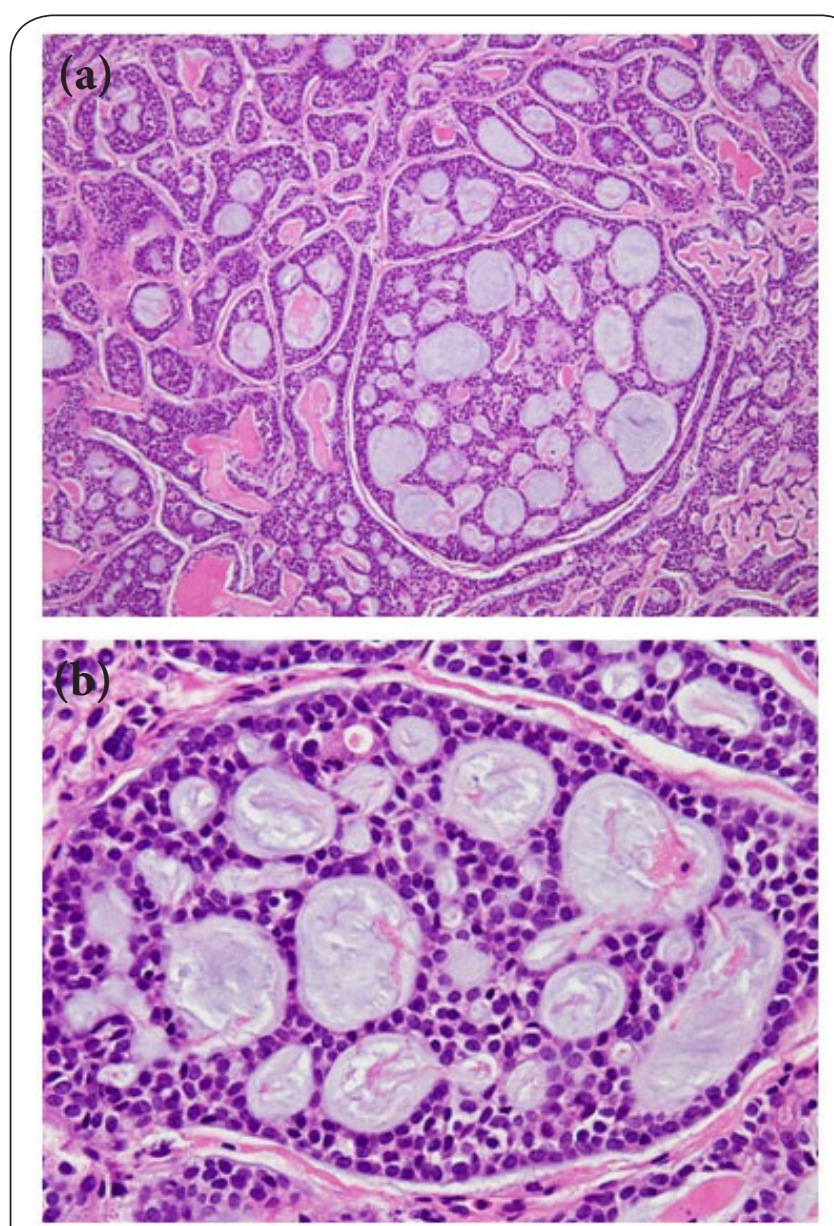

Figure 3. Histopathology of the resected tumor (Case 1). Frozen section (a) during the operation and permanent section (b) show the typical pathological features of ACC. Both show cribriform patterns of tumor cells. H\&E stain, scale bars, (a) $500 \mu \mathrm{m}$ and (b) $100 \mu \mathrm{m}$.

The patient was considered to have been stable on follow-up for 36 months.

\section{Case 2}

A 40-year-old Japanese woman was referred to our hospital for evaluation of a right upper lobe lung mass, which had been found incidentally on chest $X$-ray examination for symptoms of an acute upper respiratory infection. She did not present with any symptoms related to bronchial obstruction and had no previous medical problems. The patient had no history of smoking or recent weight loss. Her initial laboratory values, including tumor markers [CEA $0.6 \mathrm{ng} / \mathrm{ml}$; CYFRA, $1.3 \mathrm{ng} / \mathrm{ml}$ $(<3.5 \mathrm{ng} / \mathrm{ml}$ in normal)] were unremarkable, and the findings of a pulmonary function test were normal. A CT scan of the chest revealed a $30 \mathrm{~mm}$, relatively well-defined mass near B3a in her right upper lobe (Figure 5).

We diagnosed the tumor to be peripheral lung ACC via percutaneous transthoracic fine needle aspiration cytology 


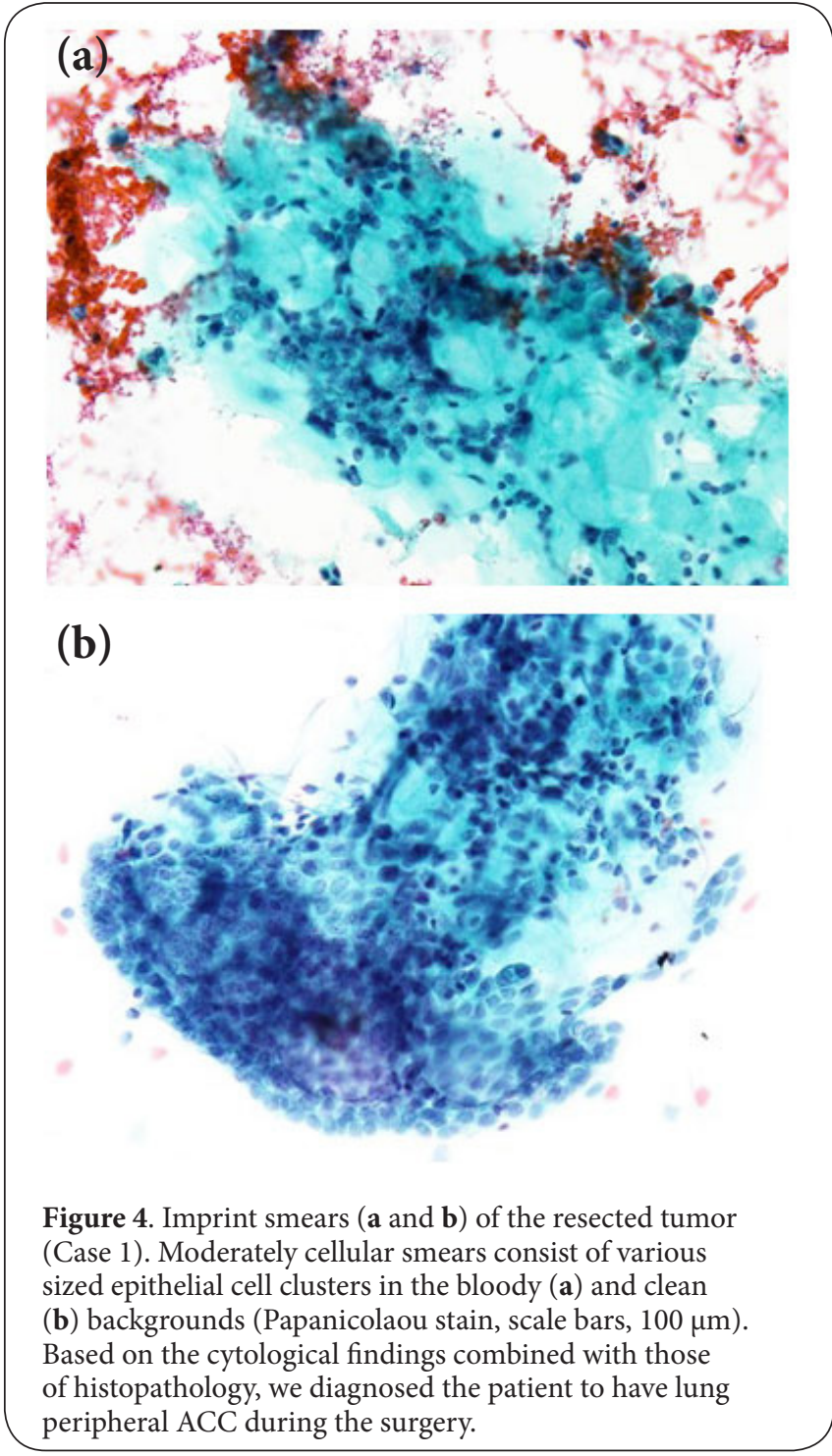

(FNAC, Figures 6a-6d) and CT-guided biopsy (Figures 7a and 7b). The patient underwent right upper lobectomy (Figure 8) with mediastinal lymph nodes dissection. The diagnosis of primary peripheral ACC was confirmed histologically. The lymph nodes were negative for metastatic disease. The postoperative course of the patient was uneventful and she is currently doing well and is being followed up on an outpatient basis.

\section{Macroscopic findings \\ Case 1}

Macroscopically, the tumor was located in the periphery of the lung parenchyma and it was not related to the main bronchus (Figure 2). The tumor was well-circumscribe and measured $11 \times 10 \times 10 \mathrm{~mm}$. The cut surface of the tumor was homogenously white. After touch imprint slides were made and fixed in 95\% ethanol for Papanicolaou staining, sections of the resected lung specimen was fixed in $10 \%$ buffered

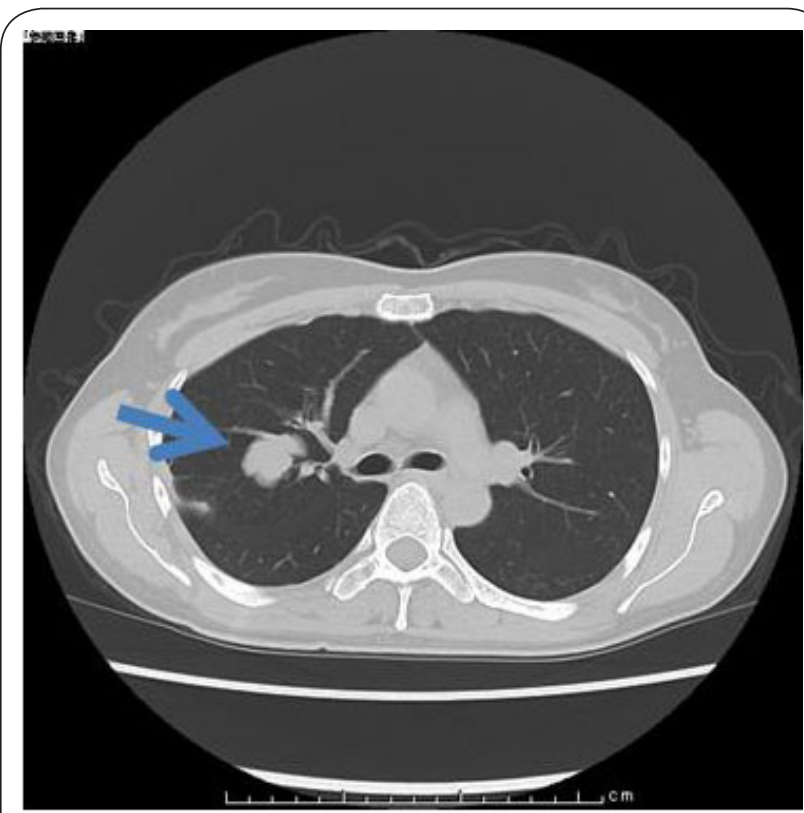

Figure 5. Chest CT shows a $30 \mathrm{~mm}$-sized, relatively welldefined mass (arrow) near the B3a in her right upper lobe (Case 2).
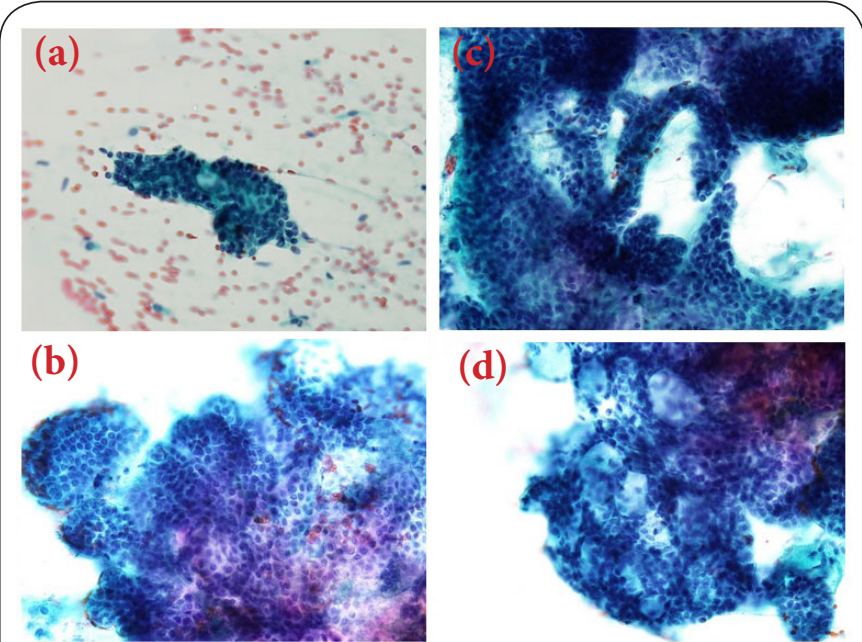

(d)

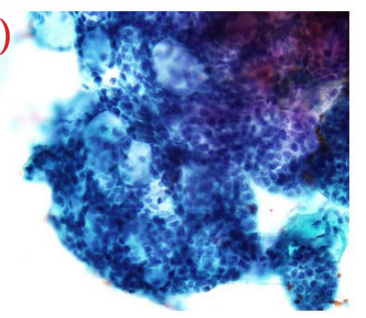

Figure 6. FNAC smears stained by the Papanicolau method (Case 2) are in the high power view. (a): Moderately cellular, mostly consisting of tightly cohesive aggregates of relatively small and uniform tumor cells on a clean background. (b-d): There are microfollicle-like structures within the tumor cell clusters resulting in a cribriform appearance. These findings suggest the presence of lung ACC. Papanicolaou stain, scale bars, $100 \mu \mathrm{m}$.

formalin for the histopathologic diagnosis. The specimen was embedded in paraffin wax, sectioned and stained with hematoxylin-eosin (H\&E), Alcian blue, and periodic acid Schiff (PAS). In addition, immunohistochemistry (Figures 9a-9n) was performed using several antibodies (Ventana/Roche, Tokyo 


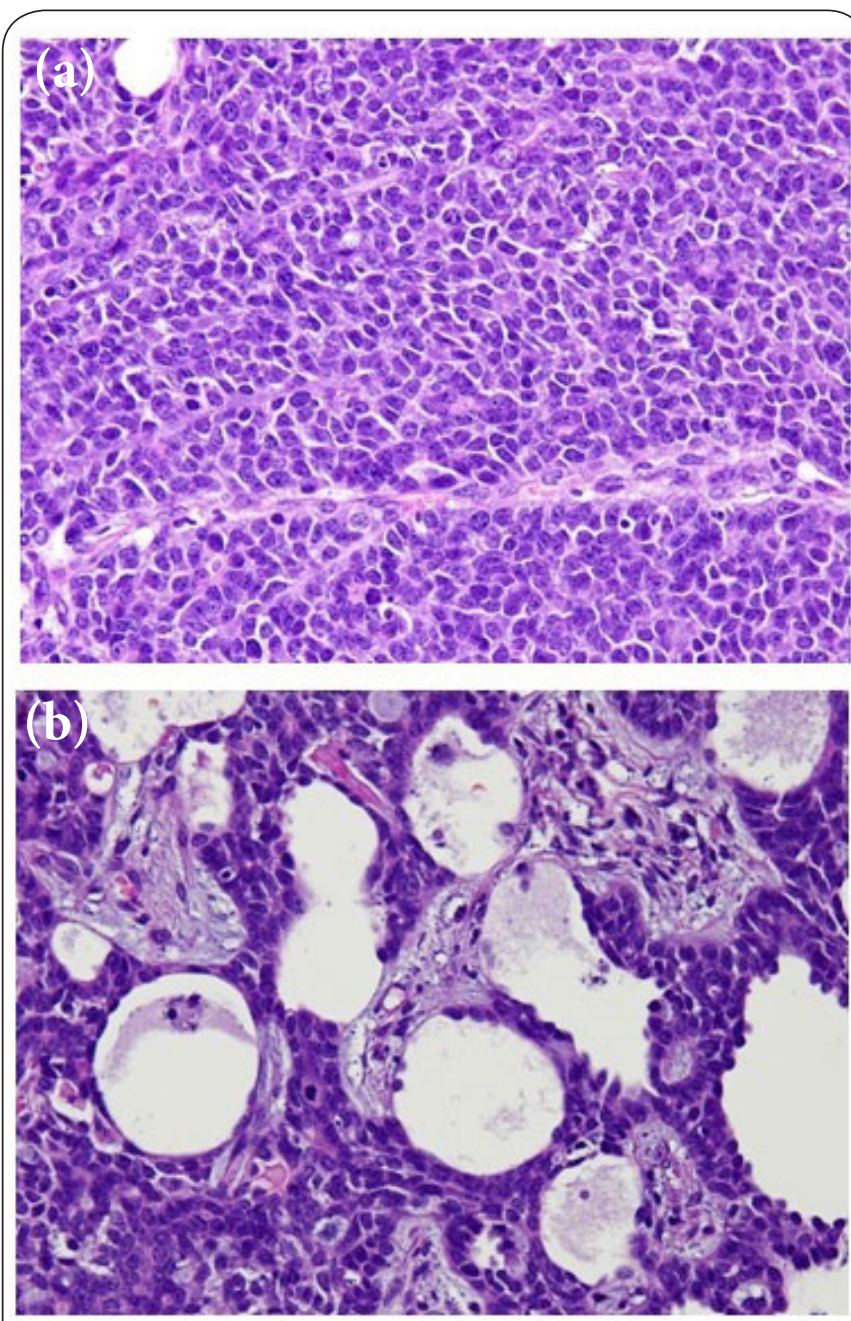

Figure 7. H\&E stained biopsy specimens (Case 2) show neoplastic cells in a solid pattern (a) and a cribriform arrangement (b). H\&E stain, scale bars, $100 \mu \mathrm{m}$.

Japan), including $A E 1 / A E 3$, a-smooth muscle actin (SMA), MIB-1, MYB, p63, TTF-1 and c-KIT.

\section{Case 2}

Examination of the right upper lobectomy specimen showed a $30 \times 24 \times 22 \mathrm{~mm}$ well-circumscribed, lobulated, white mass (Figure 8) in the periphery of the lung without any connection to the bronchial tree or submucosal extension. The mass was located $7 \mathrm{~mm}$ away from the bronchial resection margin. There was no pneumonic infiltration in the surrounding lung parenchyma, and the surgical margin was free from the tumor. Immunohistochemistry (Figures 9a-9n) using the antibodies used in Case 1 was performed to confirm the diagnosis.

\section{Microscopic findings}

Case 1

Microscopically, two small bronchi were observed at the pe-

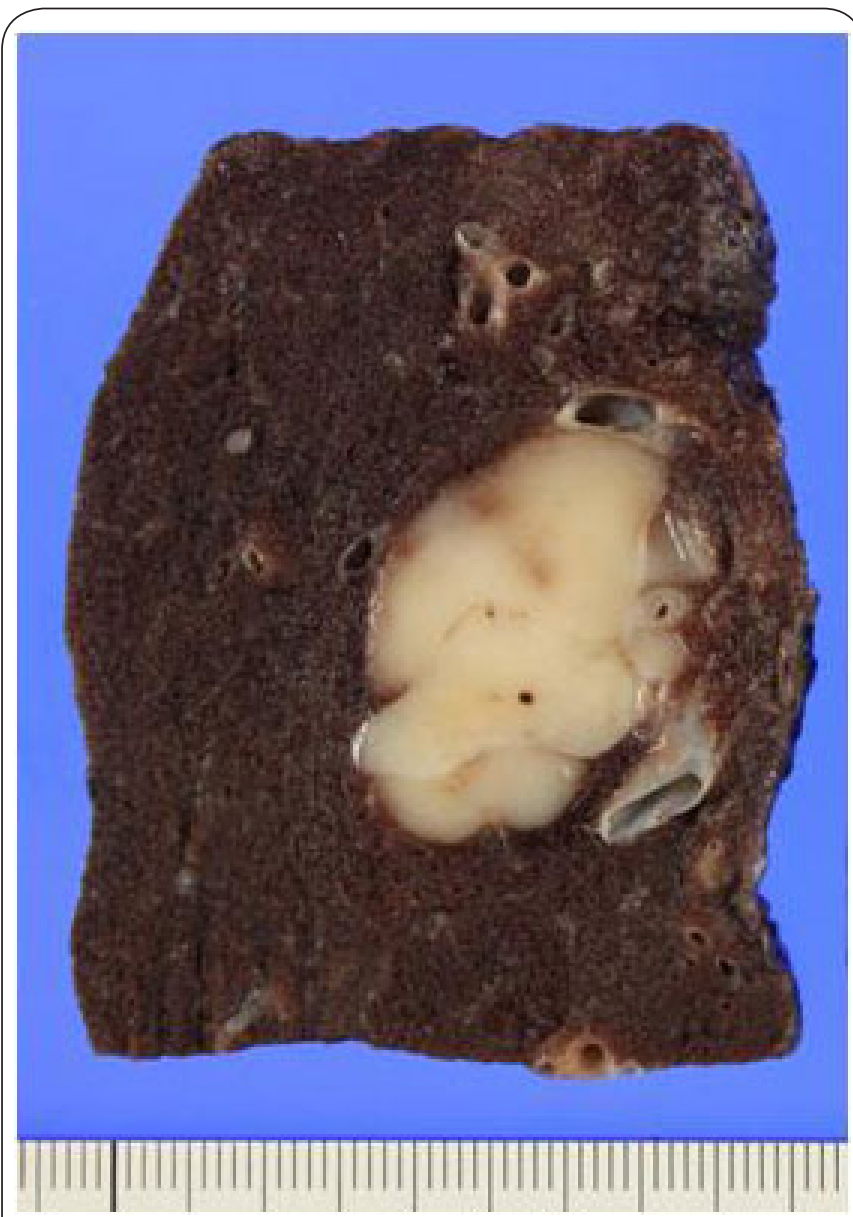

Figure 8. Macroscopic photos of the resected tumor in the right upper lobe (Case 2). Note: a lobulated tumor (30x24x22 $\mathrm{mm}$ ) is present near the B3a.

riphery of the tumor (Figure 2). The tumor consisted of two cell types, epithelial and myoepithelioid cells, with predominantly the latter cells (Figures $\mathbf{3 a}$ and $\mathbf{3} \mathbf{b}$ ). They were relatively small and uniform with round or ovoid nuclei. They formed strands or clumps with either cystic or alveolar spaces forming an interlacing cylinder and/or cribriform pattern (Figures $3 a$ and $\mathbf{3 b}$ ). The center of the cylinder or tubule was positively stained with PAS and Alcian blue.

\section{Case 2}

Tubular and solid patterns were also noted in the tumor tissue. Biopsy specimens showed epithelial and myoepithelioid neoplastic cells arranged in a solid pattern (Figure 7a). Myoepithelioid tumor cells were predominatly observed (Figures $7 \mathrm{a}$ and $7 \mathrm{~b}$ ). In the lobectomy specimen, a cribriform architecture was also seen with hyaline material within the lumina (Figure 7b). The hyaline material stained positive for Alcian blue. The tumor cells themselves were small to medium in size with slight atypia. All submitted mediastinal lymph nodes were negative for carcinoma. 


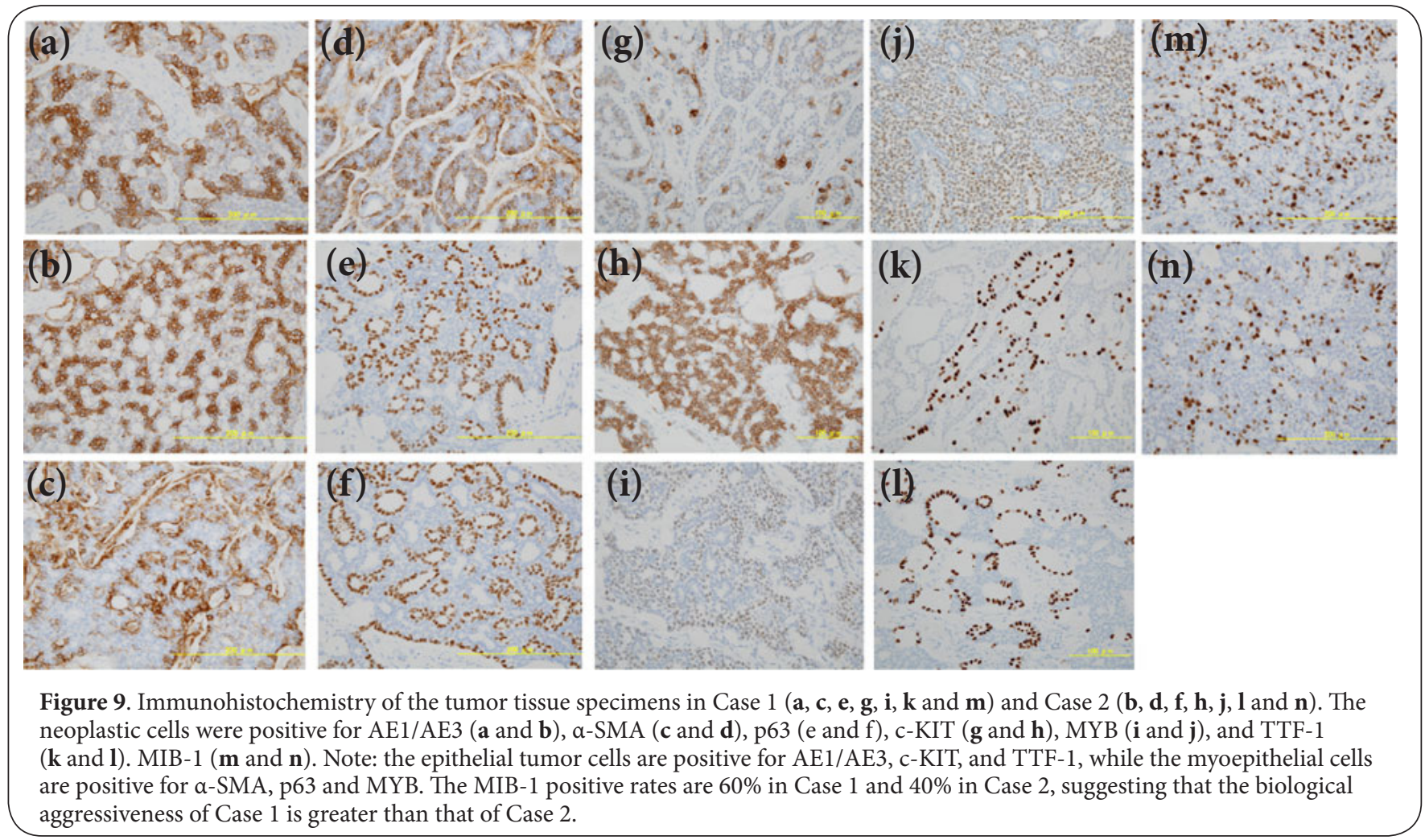

\section{Cytological findings \\ Case 1}

The touch imprint slides showed tumor cells in ball-like (Figure 4b). The cells have nuclei with fine granular chromatin and prominent nucleoli. Variably-sized central cores of homogeneous material were seen filling the cystic spaces.

\section{Case 2}

Papanicolaou-stained FNAC smears were moderately cellular, and consisted mostly of tightly cohesive aggregates of relatively small, uniform tumor cells (Figures 6a-6d). The cells were arranged in three-dimensional, tubular and spherical configurations. The tumor cells had uniform ovoid nuclei with increased nuclear to cytoplasmic ratios, and finely granular chromatin. Neoplastic clusters included acellular spheres of dense, homogeneous material that was lightly stained with Papanicolaou stain.

\section{Immunohistochemical studies}

The immunohistochemical studies from Case 1 and Case 2 were similar. Tumor cells stained positive for AE1/AE3 (Figures 9a and 9b), a-SMA (Figures $9 \mathrm{c}$ and $9 \mathrm{~d}$ ), p63 (Figures $9 \mathrm{e}$ and $9 \mathrm{f}$ ), c-KIT (Figures $9 \mathrm{~g}$ and $9 \mathbf{h}$ ), MYB (Figures $9 \mathbf{i}$ and $9 \mathbf{9 j}$ ) and TTF-1 (Figures $9 \mathbf{k}$ and $9 \mathbf{9}$ ). Case 1 had a MIB-1 (Figures $9 m$ and $9 n$ ) index of $60 \%$ and Case 2 had a MIB-1 index of $40 \%$.

\section{Discussion}

ACC mainly develops in the salivary glands and is rarely in other tissues. Primary pulmonary ACC most often develops in the lower trachea or mainstem bronchus [6] and accounts for approximately $0.2 \%$ of all cases of primary lung cancer [7]. Peripheral lung ACC is even more rare, accounting for approximately $10 \%$ of primary pulmonary ACC [8]. Bronchial glands are present from the $1^{\text {st }}$ to the $4^{\text {th }}$ order bronchi and are found in $79 \%$ of the $5^{\text {th }}$ order bronchi, and in only $11 \%$ of the $6^{\text {th }}$ order bronchi [9]. Therefore, this tumor is most commonly seen in the extra-pulmonary bronchi. Tumor arising in the intra-pulmonary bronchi is extremely rare [10-12]. We present two cases which were located in the peripheral lobe adjacent to the visceral pleura without bronchial tree involvement or submucosal extension.

In a review by Yokouchi et al., have summarized the clinical features of primary peripheral lung ACC reported in the English-language literatures [13]. Primary peripheral lung ACC is more frequently seen in males than females. The average age was 58 years and at presentation, patients are frequently asymptomatic, as was found in our cases. Most of the reported ACC cases have been accurately diagnosed and treated surgically, with favorable clinical outcomes. Only two patients had recurrence after surgery $[\mathbf{1 1}, \mathbf{1 4}]$. Because primary lung ACC is refractory to radiotherapy and chemotherapy, alternative strategies using specific ACC-targeted drugs are warranted. In this context, phase II clinical trials using imatinib mesylate, a c-KIT tyrosine kinase inhibitor, against salivary ACC have been conducted $[15,16]$ based on the evidence that this tumor 
Etori et al. Pathology Discovery 2015,

http://www.hoajonline.com/journals/pdf/2052-7896-3-3.pdf

doi: $10.7243 / 2052-7896-3-3$

expresses high levels of c-KIT protein [17-19], as shown in our cases. Salivary ACC is highly responsive to imatinib [16] and mutations of exons 9 or 11 are reported to be more important than the c-KIT protein level for the imatinib response $[19,20]$.

On histology, three growth patterns of salivary gland ACC are seen: cribriform (cylindromatous), tubular, and solid patterns [21]. The most common type is the cribriform pattern, which is also called "classic ACC". The immunohistochemical profile is also characterized by the proliferation of myoepithelial ( $\alpha$-SMA and p63) and ductal cells (AE1/AE3), as was observed in our cases. Our cases were positive for MYB and c-KIT, consistent with ACC. Tumor cells were also positive for TTF-1, indicating that the origin was the lung $[1,22,23]$. In Case 1 , the patient had a history of adenocarcinoma of the colon posing an additional diagnostic challenge. Distinguishing primary and metastatic lung ACC based on cytomorphology or histology can be difficult [6]. The lung ACC cells in the present study expressed TTF-1.TTF-1 is a protein expressesd in the forebrain, thyroid, and lung $[\mathbf{2 4}]$ and only a few reports $[\mathbf{1}, \mathbf{2 2}, \mathbf{2 3}]$ have described the expression of TTF- 1 in primary lung ACC.

Few discussions on the cytologic findings of primary peripheral lung ACC have been reported in the literature $[4,5,22]$. The cytologic findings from imprint smears (Case 1) and percutaneous FNAC (Case 2) helped us to accurately diagnose the solitary and peripheral lung tumors. Bronchial brushings have been reported to be useful for the diagnosis of primary ACCs of the lung arising from the trachea and the main bronchus $[\mathbf{2 5}, \mathbf{2 6}]$. Similarly, bronchoscopy-guided FNAC may be used to diagnose primary lung ACC arising from the main bronchus $[6,27]$. Although primary peripheral ACC of the lung rarely occurs, a preoperative accurate diagnosis should be made in cases where appropriate cytologic smears can be obtained for clinicians to provide appropriate treatment for the patient. In our two cases, we were able to diagnose peripheral lung ACC both during and before the operation, because of the typical cytological features of ACC.

Patients with a predominantly tubular growth pattern have a better prognosis than those with a solid growth pattern [28]. Interestingly, the spontaneous regression of lung ACC has also been reported [29]. Although ACC arising from the trachea or bronchus is associated with a high incidence of submucosal extension, such extension has not been described in primary peripheral ACC [8]. Our patients are both currently doing well at 3-year follow-up in Case 1 and at 2-year follow-up in Case 2. Continued follow-up is required as the potential for high-grade transformation of ACC [30] exists.

As little is known regarding the molecular pathways underlying ACC, no specific targeted agents or chemotherapy are in current use. That tumor cells stain immunohistochemically positive for C-KIT and MYB, suggest a potential role of the transmembrane tyrosine kinase receptor, C-KIT and a protooncogene for which a fusion transcript, MYB may have in the development of ACC [31] and malignant transformation [32]. The MYB-NFIB fusion transcript has been reported to be present in a specific subset of ACC and is related to MYB over-expression [33,34]. MYB immunostaining is confined to the myoepithelial cells [34] and this is seen in our cases, although such translocation was not found in our cases. These findings suggest that there are intact regulatory mechanisms in the neoplastic cells that can regulate the levels of the fusion protein. As C-KIT and MYB may play some role in the ACC pathogenesis, C-KIT and MYB may be good targets for future therapeutic management.

\section{Conclusion}

We herein described two patients with primary peripheral lung ACC. Although rare, ACC should be considered in the differential diagnosis of a primary lung tumor, even when present in the peripheral lung.

\section{Competing interests}

The authors declare that they have no competing interests.

\section{Authors' contributions}

\begin{tabular}{|l|l|l|l|l|l|l|l|l|l|l|l|}
\hline $\begin{array}{l}\text { Authors' } \\
\text { contributions }\end{array}$ & FE & NW & MM & NK & AS & KN & TS1 & TS2 & TM & TN & TT \\
\hline $\begin{array}{l}\text { Research concept } \\
\text { and design }\end{array}$ & $\checkmark$ & $\checkmark$ & -- & -- & -- & -- & -- & $\checkmark$ & $\checkmark$ & $\checkmark$ & $\checkmark$ \\
\hline $\begin{array}{l}\text { Collection and/or } \\
\text { assembly of data }\end{array}$ & $\checkmark$ & -- & $\checkmark$ & $\checkmark$ & $\checkmark$ & $\checkmark$ & $\checkmark$ & $\checkmark$ & $\checkmark$ & -- & -- \\
\hline $\begin{array}{l}\text { Data analysis and } \\
\text { interpretation }\end{array}$ & $\checkmark$ & $\checkmark$ & $\checkmark$ & $\checkmark$ & $\checkmark$ & $\checkmark$ & $\checkmark$ & $\checkmark$ & $\checkmark$ & $\checkmark$ & $\checkmark$ \\
\hline Writing the article & $\checkmark$ & $\checkmark$ & -- & -- & -- & -- & -- & -- & -- & -- & $\checkmark$ \\
\hline $\begin{array}{l}\text { Critical revision of } \\
\text { the article }\end{array}$ & $\checkmark$ & $\checkmark$ & -- & -- & -- & -- & -- & -- & -- & $\checkmark$ & $\checkmark$ \\
\hline $\begin{array}{l}\text { Final approval of } \\
\text { article }\end{array}$ & $\checkmark$ & $\checkmark$ & $\checkmark$ & $\checkmark$ & $\checkmark$ & $\checkmark$ & $\checkmark$ & $\checkmark$ & $\checkmark$ & $\checkmark$ & $\checkmark$ \\
\hline Statistical analysis & -- & -- & -- & -- & -- & -- & -- & -- & -- & -- & -- \\
\hline
\end{tabular}

\section{Acknowledgement}

This study was supported in part by Grants-in-Aid from the Ministry of Education, Science, Sports and Culture of Japan (No. 90157206).

\section{Publication history}

Editor: Jianyu Rao, Ucla Ronald Reagan Medical Center, USA. EIC: Markus H. Frank, Harvard Medical School, USA. Received: 11-Mar-2015 Final Revised: 11-Apr-2015 Accepted: 13-Apr-2015 Published: 17-Apr-2015

\section{References}

1. Kim JH, Ahn SH, Kim JM and Lee SY. Metachronous adenoid cystic carcinoma in the peripheral lung and at base of the tongue. Clin Exp Otorhinolaryngol. 2014; 7:232-5. | Article | PubMed Abstract | PubMed Full Text

2. Travis WD, Travis LB and Devesa SS. Lung cancer. Cancer. 1995; 75:191202. I PubMed

3. Molina JR, Aubry MC, Lewis JE, Wampfler JA, Williams BA, Midthun DE, Yang $P$ and Cassivi SD. Primary salivary gland-type lung cancer: spectrum of clinical presentation, histopathologic and prognostic factors. Cancer. 2007; 110:2253-9. I Article I PubMed

4. Chon SH, Park YW, Oh YH and Shinn SH. Primary peripheral pulmonary adenoid cystic carcinoma: report of a case diagnosed by fine needle aspiration cytology. Diagn Cytopathol. 2011; 39:283-7. | Article | PubMed 
5. Nonomura A, Mizukami Y, Nakamura S, Watanabe Y, Takashima T, Tanimoto $\mathrm{K}$ and Kitagawa M. Peripheral adenoid cystic carcinoma of the lung - a case report. J. Jpn. Soc. Clin. Cytol. 1992; 31:998-1003. I Pdf

6. Qiu S, Nampoothiri MM, Zaharopoulos P and Logrono R. Primary pulmonary adenoid cystic carcinoma: report of a case diagnosed by fine-needle aspiration cytology. Diagn Cytopathol. 2004; 30:51-6. | Article I PubMed

7. Sweeney WB and Thomas JM. Adenoid cystic carcinoma of the lung. Contemp. Surg. 1986; 28:97-100.

8. Inoue $H$, Iwashita A, Kanegae $H$, Higuchi $K$, Fujinaga $Y$ and Matsumoto I. Peripheral pulmonary adenoid cystic carcinoma with substantial submucosal extension to the proximal bronchus. Thorax. 1991; 46:1478. | Article | PubMed Abstract | PubMed Full Text

9. Mitani S. Studies on distribution and histological observation of mucus gland in the bronchial tree of adult human lungs (in Japanese with English abstract). Haigan. 1974; 14:21-29. | Article

10. Dalton ML and Gatling RR. Peripheral adenoid cystic carcinoma of the lung. South Med J. 1990; 83:577-9. I Article I PubMed

11. Gallagher CG, Stark R, Teskey J and Kryger M. Atypical manifestations of pulmonary adenoid cystic carcinoma. Br J Dis Chest. 1986; 80:396-9. | Article I PubMed

12. Okura T, Shiode M, Tanaka R, Furukawa A and Kukita H. [A case of peripheral adenoid cystic carcinoma]. Nihon Kyobu Shikkan Gakkai Zasshi. 1990; 28:773-6. | Article | PubMed

13. Walter JB and Pryce DM. The site of origin of lung cancer and its relation to histological type. Thorax. 1955; 10:117-26. | Article I PubMed Abstract I PubMed Full Text

14. Goldman A and Conner CL. Benign tumors of the lungs with special reference to adenomatous bronchial tumors. Dis Chest. 1950; 17:64480. I Pdf | PubMed

15. Hotte SJ, Winquist EW, Lamont E, MacKenzie M, Vokes E, Chen EX, Brown S, Pond GR, Murgo A and Siu LL. Imatinib mesylate in patients with adenoid cystic cancers of the salivary glands expressing c-kit: a Princess Margaret Hospital phase II consortium study. J Clin Oncol. 2005; 23:58590. | Article | PubMed

16. Faivre S, Raymond E, Casiraghi O, Temam S and Berthaud P. Imatinib mesylate can induce objective response in progressing, highly expressing KIT adenoid cystic carcinoma of the salivary glands. J Clin Oncol. 2005; 23:6271-3. | Article I PubMed

17. Holst VA, Marshall CE, Moskaluk CA and Frierson HF, Jr. KIT protein expression and analysis of c-kit gene mutation in adenoid cystic carcinoma. Mod Pathol. 1999; 12:956-60. | Article | PubMed

18. Miettinen M and Lasota J. KIT (CD117): a review on expression in normal and neoplastic tissues, and mutations and their clinicopathologic correlation. Appl Immunohistochem Mol Morphol. 2005; 13:205-20. | Article | PubMed

19. Went PT, Dirnhofer S, Bundi M, Mirlacher M, Schraml P, Mangialaio S, Dimitrijevic S, Kononen J, Lugli A, Simon R and Sauter G. Prevalence of KIT expression in human tumors. J Clin Oncol. 2004; 22:4514-22. | Article I PubMed

20. Sihto H, Sarlomo-Rikala M, Tynninen O, Tanner M, Andersson LC, Franssila K, Nupponen NN and Joensuu H. KIT and platelet-derived growth factor receptor alpha tyrosine kinase gene mutations and KIT amplifications in human solid tumors. J Clin Oncol. 2005; 23:49-57. | Article I PubMed

21. Moran CA. Primary salivary gland-type tumors of the lung. Semin Diagn Pathol. 1995; 12:106-22. | Article | PubMed

22. Yokouchi H, Otsuka Y, Otoguro Y, Takemoto N, Ito K, Uchida Y, Okamoto $\mathrm{K}$, Nishimura M, Kimura K and Kaji H. Primary peripheral adenoid cystic carcinoma of the lung and literature comparison of features. Intern Med. 2007; 46:1799-803. | Article | PubMed

23. Kitada M, Ozawa K, Sato K, Hayashi S, Tokusashi Y, Miyokawa N and Sasajima T. Adenoid cystic carcinoma of the peripheral lung: a case report. World J Surg Oncol. 2010; 8:74. | Article | PubMed Abstract | PubMed Full Text

24. Maeda Y, Dave V and Whitsett JA. Transcriptional control of lung morphogenesis. Physiol Rev. 2007; 87:219-44. | Article | PubMed

25. Segletes LA, Steffee CH and Geisinger KR. Cytology of primary pulmonary mucoepidermoid and adenoid cystic carcinoma. A report of four cases. Acta Cytol. 1999; 43:1091-7. I Article I PubMed

26. Chuah KL, Lim KH, Koh MS, Tan HW and Yap WM. Diagnosis of adenoid cystic carcinoma of the lung by bronchial brushing: a case report. Acta Cytol. 2007; 51:563-6. | PubMed

27. Ozkara SK and Turan G. Fine needle aspiration cytopathology of primary solid adenoid cystic carcinoma of the lung: a case report. Acta Cytol. 2009; 53:707-10. | Article | PubMed

28. Azukari K, Yoshioka K, Seto S, Ueno M, Yasukawa M and Tatebe A. Adenoid cystic carcinoma arising in the intrapulmonary bronchus. Intern Med. 1996; 35:407-9. | Article | PubMed

29. Kumar T, Patel N and Talwar A. Spontaneous regression of thoracic malignancies. Respir Med. 2010; 104:1543-50. | Article | PubMed

30. Sayar H, Sarioglu S, Bakaris S, Yildirim I and Oztarakci H. High-grade transformation of adenoid cystic carcinoma delineated with a fibrous rim: a case report. Balkan Med J. 2013; 30:333-6. | PubMed Abstract | PubMed Full Text

31. Vila L, Liu H, Al-Quran SZ, Coco DP, Dong HJ and Liu C. Identification of c-kit gene mutations in primary adenoid cystic carcinoma of the salivary gland. Mod Pathol. 2009; 22:1296-302. | Article | PubMed Abstract | PubMed Full Text

32. Liu J, Shao C, Tan ML, Mu D, Ferris RL and Ha PK. Molecular biology of adenoid cystic carcinoma. Head Neck. 2012; 34:1665-77. | Article | PubMed Abstract | PubMed Full Text

33. Mitani Y, Li J, Rao PH, Zhao YJ, Bell D, Lippman SM, Weber RS, Caulin $\mathrm{C}$ and El-Naggar AK. Comprehensive analysis of the MYB-NFIB gene fusion in salivary adenoid cystic carcinoma: Incidence, variability, and clinicopathologic significance. Clin Cancer Res. 2010; 16:4722-31. | Article | PubMed

34. West RB, Kong C, Clarke N, Gilks T, Lipsick JS, Cao H, Kwok S, Montgomery KD, Varma $S$ and Le QT. MYB expression and translocation in adenoid cystic carcinomas and other salivary gland tumors with clinicopathologic correlation. Am J Surg Pathol. 2011; 35:92-9. | Article | PubMed Abstract | PubMed Full Text

\section{Citation:}

Etori F, Watanabe N, Matsuyama M, Kawaguchi N, Sekiya A, Nambu K, Sakakima T, Sawa T, Marui T, Naiki T and Tanaka T. Primary adenoid cystic carcinoma in the peripheral lung: a cytological, histopathological and immunohistochemical report of two cases. Pathol Discov. 2015; 3:3. http://dx.doi.org/10.7243/2052-7896-3-3 